\title{
Mapping a Resistance Gene to Puccinia graminis f. sp. tritici in the Bread Wheat Cultivar 'Matlabas'
}

\author{
Elsabet Wessels, ${ }^{1, \dagger}$ Renée Prins, ${ }^{1,2,3}$ Willem H. P. Boshoff, ${ }^{3}$ Jason D. Zurn, ${ }^{4}$ Maricelis Acevedo, ${ }^{5}$ and Zacharias A. Pretorius ${ }^{3}$ \\ ${ }^{1}$ CenGen (Pty) Ltd., Worcester, 6850, South Africa \\ ${ }^{2}$ Department of Genetics, Stellenbosch University, Matieland, 7602, South Africa \\ ${ }^{3}$ Department of Plant Sciences, University of the Free State, Bloemfontein, 9300, South Africa \\ ${ }^{4}$ Department of Plant Pathology, North Dakota State University, Fargo, ND, U.S.A., and USDA-ARS, National Clonal Germ- \\ plasm Repository, Corvallis, OR, U.S.A. \\ ${ }^{5}$ Office of International Programs - CALS, Cornell University, Ithaca, NY, U.S.A.
}

\begin{abstract}
Puccinia graminis f. sp. tritici race TTKSF+ was collected from the South African wheat cultivar 'Matlabas' in 2010. $\mathrm{F}_{2}$ and $\mathrm{F}_{3}$ populations derived from a Matlabas $\times$ Line 37-07 cross segregated for a single resistance gene to race TTKSF that is avirulent to Matlabas. In screening genomic DNA bulks of susceptible or resistant $F_{2}$ plants with simple sequence repeat (SSR) markers, three chromosome arm 2BS markers and one multilocus marker amplified alleles present only in the resistant bulks and Matlabas. Additional 2B-specific SSR markers, incorporating markers spanning regions containing $\operatorname{Sr} 9 h, \operatorname{SrWLR}, \mathrm{Sr} 28$, and $\mathrm{Sr} 47$, were screened in the parental lines and mapped in the $\mathrm{F}_{2}$ population. Linkage and QTL mapping showed that the gene is located between Xbarc160 in the centromeric region

and Xgwm47 on the long arm of chromosome 2B. When 2B-specific SNP markers were mapped, the area of interest was delimited to a $15.3 \mathrm{cM}$ region on chromosome arm 2BL, with XIWA543-HRM and $\mathrm{Xgwm} 47$ as flanking loci. Matlabas, Webster, and related $\mathrm{Sr} 9 \mathrm{~h}$ lines all produced a similar, low infection type to race TTKSF, but were susceptible to race TTKSF+. Phenotypic data and allelic studies suggested that stem rust resistance in Matlabas was derived from an $\mathrm{Sr} 9 \mathrm{~h}$ source.

Keywords: fungi, field crops, cereals and grains, disease management, cultivar/resistance, epidemiology, disease development and spread, pathogen diversity
\end{abstract}

The detection of the African Puccinia graminis Pers. f. sp. tritici Eriks. \& E. Henn race TTKSK (Ug99) stimulated research on wheat stem rust (Jin et al. 2008; McIntosh and Pretorius 2011; Pretorius et al. 2000; Singh et al. 2011, 2015). Given that Ug99 and its related races are virulent on most wheat (Triticum aestivum L.) cultivars (Singh et al. 2015), stem rust surveillance and race analyses have been a distinctive focus worldwide (Hodson 2011; Park et al. 2011). In addition to the original description of Ug99 (Pretorius et al. 2000), detection of related races with new virulence profiles raises serious concerns about the threat posed by this adaptable $P$. graminis f. sp. tritici race group. At present, 13 variants have been described with virulence gains for the major resistance genes $\mathrm{Sr} 9 \mathrm{~h}$, Sr24, Sr36, and SrTmp (Patpour et al. 2016; Singh et al. 2015). According to https://rusttracker.cimmyt.org Ug99-lineage races have been detected in 11 African countries as well as Yemen and Iran.

Race TTKSF was first detected in South Africa in 2000 (Boshoff et al. 2002) and has since dominated the local $P$. graminis f. sp. tritici population (Terefe et al. 2016). Although TTKSF lacks virulence for Sr31, Visser et al. (2009) provided evidence that this race belongs to the Ug99 group. In 2010, a race classified as TTKSF+ was collected from the severely stem rust infected bread wheat cultivar 'Matlabas' in the eastern Free State, South Africa (Pretorius et al. 2012).

${ }^{\dagger}$ Corresponding author: E. Wessels; elsabet@cengen.co.za

Funding: This work was partly funded by the South African Winter Cereal Trust and the National Research Foundation.

*The $\boldsymbol{e}$-Xtra logo stands for "electronic extra" and indicates that three supplementary figures and one supplementary table are published online.

The author(s) declare no conflict of interest.

Accepted for publication 8 April 2019.

(C) 2019 The American Phytopathological Society
'Matlabas', developed by ARC-Small Grains, was released for winter wheat production under dryland conditions in the Free State in 2004 (Anonymous 2007; Smit et al. 2010). The cultivar was favored by growers due to its preharvest sprouting tolerance, excellent straw strength, and standability. Plantings of 'Matlabas' increased steadily and contributed an estimated $18.2 \%$ of winter wheat grain produced in the eastern Free State in 2010 (Anonymous 2011).

The objectives of this study were to use pathogenicity tests and a QTL mapping approach to locate the chromosome position and determine the identity of the 'Matlabas' stem rust $(\mathrm{Sr})$ resistance gene. In addition to accurately documenting diversity in $P$. graminis $\mathrm{f}$. $\mathrm{sp}$. tritici, confirmation of the resistance gene which became ineffective in 'Matlabas' will allow its detection in other wheat germplasm and add to descriptions of stem rust vulnerability.

\section{Materials and Methods}

Plant material. An $\mathrm{F}_{2}$ population and $\mathrm{F}_{3}$ families were developed from a cross between 'Matlabas' (pedigree: Saulesku-28/TugelaDN) and stem rust-susceptible Line 37-07. Line 37-07 was selected as entry 37 (pedigree: Kasyob/Genaro-81//Cham4) of the 2nd International Stem Rust Trap Nursery (ISRTN07) based on its susceptibility to stem rust in field trials in South Africa. All progeny were derived from a cross between a single plant of each parent. Due to the vernalization requirement of offspring, $F_{3}$ families were advanced from $\mathrm{F}_{2}$ plants which were different than those phenotyped as seedlings. The $\mathrm{F}_{3}$ families were selected without prior knowledge of their stem rust response, and each contained a minimum of 30 plants per family. To test for an allelic relationship between the resistance gene in 'Matlabas' and $\mathrm{Sr} 9 \mathrm{~h}$, 'Matlabas' was crossed with 'Webster', CItr 4311, and an $\mathrm{F}_{3}$ selection from a RL6071 $\times$ Webster cross. The presence of $\mathrm{Sr} 9 \mathrm{~h}$ has been confirmed in these lines (Babiker et al. 2016b; Hiebert et al. 2010; Rouse et al. 2014). $F_{2}$ populations were developed from a single $\mathrm{F}_{1}$ spike for each cross. Additional $\mathrm{Sr}$ gene tester lines (Tables 1 and 2) were included for phenotypic and/or molecular assessments. These lines were selected because they carry $\mathrm{Sr}$ genes on either the short or long arm of wheat 
chromosome $2 \mathrm{~B}$, the target gene location suggested by initial mapping results.

Assessments of phenotype. 'Matlabas', Line 37-07, 247 Matlabas $\times$ Line $37-07 \mathrm{~F}_{2}$ plants, 79 Matlabas $\times$ Line $37-07 \mathrm{~F}_{3}$ families, and the $\mathrm{Sr}$ gene tester lines were evaluated in the seedling stage for their response to $P$. graminis f. sp. tritici race TTKSF (isolate UVPgt55_04/ 2002). This race is avirulent on 'Matlabas' and virulent on Line 3707. Once assessment of $F_{3}$ families with TTKSF was completed, those families homozygous for resistance, and all tester lines, were also inoculated with $P$. graminis $\mathrm{f}$. sp. tritici race TTKSF+ (isolate UVPgt61/1_13/07/2011) which is virulent on 'Matlabas'. For the allelism tests, $\mathrm{F}_{2}$ seedlings of Matlabas $\times$ Webster, Matlabas $\times$ CItr 4311, and Matlabas $\times$ RL6071/Webster together with the respective parents, were tested for resistance to race TTKSF. For all seedling tests, seed was sown in a sterilized soil-peat moss (50:50) mixture in 10-cmdiameter pots which were maintained in a growth chamber at $22^{\circ} \mathrm{C}$ until seedling emergence, before placement at 18 to $23^{\circ} \mathrm{C}$ under natural light in a greenhouse. Primary leaves of plants were inoculated 8 days after sowing with a $5 \mathrm{mg} / \mathrm{ml}$ suspension of urediniospores in Soltrol 130 (Chevron Phillips Chemical Company, The Woodlands, TX) light mineral oil. After drying for $1 \mathrm{~h}$, plants were placed in a dark dew chamber for $16 \mathrm{~h}$. Upon removal, seedlings were dried for $3 \mathrm{~h}$ under light in a growth chamber and returned to the greenhouse under the same conditions as before. Infection types (0 to 4 scale, Stakman et al. 1962) were scored 13 days postinoculation. All seedling tests were repeated except for the $\mathrm{F}_{2}$ and $\mathrm{F}_{3}$ Matlabas $\times$ Line 37-07 germplasm, for which limited genetic stocks were available.

Molecular analysis, linkage mapping, and QTL analysis. Following phenotyping, leaf samples were collected from the respective resistant or susceptible Matlabas $\times$ Line $37-07 \mathrm{~F}_{2}$ plants and the parents at the three-leaf stage and freeze-dried for genomic DNA (gDNA) extraction. A CTAB (cetyltrimethyl ammonium bromide) DNA extraction method was used (Doyle and Doyle 1990). The gDNA was quantified with a Nanodrop Spectrophotometer ND1000 (Thermo Scientific, Wilmington, DE) and diluted to a working concentration of $25 \mathrm{ng} / \mu \mathrm{l}$. One susceptible (S) and two resistant (R) gDNA bulks, consisting of 10 randomly selected $\mathrm{F}_{2}$ plants each, were constructed using equimolar amounts of DNA (Michelmore et al. 1991). The individuals in the R-bulks could have been either homozygous or heterozygous resistant.

The parental lines and the bulks were then screened with a low resolution genome scan (LRGS) marker set consisting of 104 microsatellite (SSR) markers (Wessels and Prins 2017). The polymerase chain reaction
(PCR) mixtures contained $0.08 \mathrm{mM}$ of each deoxynucleotide, $1.5 \mathrm{mM}$ $\mathrm{MgCl}_{2}, 0.25 \mathrm{U} \mathrm{Taq}$ polymerase, and 3 to $10 \mathrm{pmol}$ of fluorescently labeled primer, depending on the primer's amplification efficiency. PCR products were analyzed on a 3730xl DNA Analyzer (Applied Biosystems Inc., Foster City, CA) at the Central Analytical Facility of Stellenbosch University, South Africa. GeneScan 500 LIZ size standard (Applied Biosystems Inc.) was used as an internal size standard. The data were analyzed using GeneMapper V4.0 (Applied Biosystems Inc.).

Once marker-trait confirmation was obtained, the 2B linkage map for the Matlabas $\times$ Line $37-07 \mathrm{~F}_{2}$ population was improved by screening additional chromosome $2 \mathrm{~B}$-specific SSRs in the parental lines with a focus to incorporate as many SSR markers as possible reported to span regions containing $\mathrm{Sr} 9 \mathrm{~h}$ (previously $\mathrm{SrWeb}$ ), SrWLR, and Sr28 (Appels 2003; Bansal et al. 2012; Hiebert et al. 2010; Rouse et al. 2012, 2014; Somers et al. 2004; Sourdille et al. 2004; Zurn et al. 2014). Furthermore, single nucleotide polymorphism (SNP) markers on the 9K Illumina Infinium iSelect wheat assay (Cavanagh et al. 2013) that previously mapped to the region of interest (Zurn et al. 2014) were converted to high resolution meltcurve (HRM) markers (Supplementary Table S1) using Primer3 V4.0.0 (Koressaar and Remm 2007; Untergasser et al. 2012). The parents were initially screened with these markers to confirm polymorphism. The real-time PCR reaction mixture contained 1× Kapa HRM Fast PCR Kit (Kapa Biosystems, Cape Town, South Africa), $2.5 \mathrm{mM} \mathrm{MgCl}$, and 3 pmol primer. Reactions were performed in a Bio-Rad CFX96 real-time thermocycler (Bio-Rad Laboratories (Pty) Ltd., Hercules, CA), and the data were analyzed with BioRad CFX Manager software V3.1 and Bio-Rad Precision Melt Analysis software V1.2 (Bio-Rad Laboratories (Pty) Ltd.).

To ensure a linkage map of high quality, only codominant polymorphic SSR and HRM markers were then screened in the $\mathrm{F}_{2}$ population. Several markers previously reported to be associated with stem rust resistance on chromosome $2 \mathrm{BL}$ were included in the parental screens, but were not screened in the Matlabas $\times$ Line $37-07 \mathrm{~F}_{2}$ population for various reasons: GWM388, BARC101, CFD73, WMC332, BARC128, WMC477 (not polymorphic), GWM120 (dominant marker), and WMC360 (complex profile; Akbari et al. 2006; Bansal et al. 2012; Hiebert et al. 2010; Somers et al. 2004; Tsilo et al. 2007). Nine markers spanning the chromosome $2 \mathrm{~B}$ region in which the Matlabas gene was mapped were also used to genotype selected chromosome $2 \mathrm{~B}$ control lines and resistant and susceptible Matlabas $\times$ Line $37-07 \mathrm{~F}_{3}$ families.

Based on the results obtained from the bulk and parental screen, three chromosome $2 \mathrm{~B}$ markers, putatively associated with the

Table 1. Infection types of wheat lines with $S r$ genes known to occur on chromosome 2B to Puccinia graminis f. sp. tritici races TTKSF and TTKSF+

\begin{tabular}{|c|c|c|c|c|c|}
\hline Line & $S r$ gene & Chrom. location & Source & TTKSF & TTKSF+ \\
\hline ISr9a-Ra CI14169 & $9 a$ & $2 \mathrm{BL}$ & Seventh ISRTN\#8 & 4 & 4 \\
\hline Prelude*4/2/Mq*6/K117A & $9 b$ & $2 \mathrm{BL}$ & Seventh ISRTN\#9 & 4 & 4 \\
\hline ISr9d-Ra CI14177 & $9 d$ & $2 \mathrm{BL}$ & Seventh ISRTN\#10 & 4 & 4 \\
\hline Vernstein PI 442914 & $9 e$ & $2 \mathrm{BL}$ & Seventh ISRTN\#11 & 4 & 4 \\
\hline Acme & $9 g$ & $2 \mathrm{BL}$ & UFS II-25 & 4 & 4 \\
\hline W2691Sr10 CI 17388 & $10^{\circ}$ & $2 \mathrm{BL}$ & Seventh ISRTN\#13 & 4 & 4 \\
\hline Thatcher/CS CI 14173 & 16 & $2 \mathrm{BL}$ & Seventh ISRTN\#19 & $3+$ & $3++$ \\
\hline 94A 236-1Marquis "B" & 19 & $2 \mathrm{BS}$ & Seventh ISRTN\#23 & 4 & 4 \\
\hline 94A 237-1 Marquis "C" & 20 & $2 \mathrm{BL}$ & Seventh ISRTN\#24 & 4 & 4 \\
\hline Exchange & 23 & $2 \mathrm{BS}$ & Seventh ISRTN\#28 & $3+$ & 4 \\
\hline Kota RL471 & 28 & $2 \mathrm{BL}$ & Seventh ISRTN\#33 & ;12 & $; ; 1$ \\
\hline W2691SrTt-1 & 36 & 2BS & UFS II-74 & 0 & 0 \\
\hline $2 \mathrm{~S} \# 2 / 163$ & 39 & $2 \mathrm{BS}$ & UFS II-111 & ; & $1=$ \\
\hline RL5711 & 39 & 2BS & Seventh ISRTN\#46 & 1 & 1 \\
\hline RL6087 & 40 & $2 \mathrm{BS}$ & Seventh ISRTN\#47 & 1 & 1 \\
\hline DAS 15 & 47 & $2 \mathrm{BS}$ & $\mathrm{CDL}$ & ;1- & ;1- \\
\hline LCSrWst-2Wst & $W s t-2$ & $-\mathrm{a}$ & UFS II- 80 & 1 & 4 \\
\hline Matlabas & $?$ & $2 \mathrm{BL}$ & UFS CV2011\#84 & $1+$ & 4 \\
\hline Webster & $9 h$ & $2 \mathrm{BL}$ & CRC CM661 & 2 & $3+$ \\
\hline RL6071/Webster F3 & $9 h$ & $2 \mathrm{BL}$ & CRC CM664 & 2 & $3++$ \\
\hline RL6071 & Susc. contr. & - & CRC CM354 & $3+$ & $3++$ \\
\hline PI 626573-2 & SrWLR & $2 \mathrm{BL}$ & PI 626573-2 & $2-$ & $33+$ \\
\hline
\end{tabular}

${ }^{a}$ Not yet confirmed. 
resistance gene, were screened on 186 individual $\mathrm{F}_{2}$ plants to create a preliminary, partial linkage map of chromosome 2B with JoinMap V4.1 using an independence test LOD score of 10 for linkage group formation (Van Ooijen 2006). The map was constructed using the Monte Carlo Maximum likelihood (ML) mapping algorithm (Van Ooijen 2011) and the Kosambi mapping function (Kosambi 1943). A final linkage map was constructed with the complete dataset (including additional polymorphic SSR and HRM markers). To avoid using the trait as a dominant marker in an $\mathrm{F}_{2}$ population, a QTL mapping approach was followed. For QTL analysis, phenotypic data were converted to " 1 " (for susceptible plants) and " 0 " (for resistant plants). Kruskal-Wallis single marker trait associations were calculated and interval mapping (IM) was performed using MapQTL V6 (Van Ooijen 2009). Default parameters were used with the number of permutations set at 10,000 to determine QTL significance.

\section{Results}

Assessments of phenotype. Matlabas $\times$ Line $37-07 \mathrm{~F}_{2}$ plants and $\mathrm{F}_{3}$ families segregated for a single resistance gene to TTKSF. In the $\mathrm{F}_{2}$ generation, $74 \%$ of the plants were resistant, showing a clear $1+$ to
2 infection type, whereas $26 \%$ were susceptible (Supplementary Fig. S1). 'Matlabas' produced infection type 1+ to TTKSF and Line 3707 a distinctively more susceptible $3++$ infection type. The $\chi^{2}$ value $\left(\chi^{2}\right)$ of $0.228(P=0.663)$ did not deviate from the expected ratio for single, dominant gene inheritance $(3: 1)$ in the $F_{2}$ generation. $F_{3}$ families segregated in a 15 homozygous resistant, 52 segregating, and 12 homozygous susceptible ratio $\left(\chi^{2}=8.139, P=0.017\right)$ which deviated from the expected 1:2:1 ratio. Both parents and all $\mathrm{F}_{3}$ families homozygous for resistance to TTKSF were susceptible to TTKSF+ (infection types $3+$ to 4$)$. All $F_{2}$ progeny from each of the crosses Matlabas $\times$ Webster ( $n=527$ seedlings), Matlabas $\times$ CItr $4311(n=628$ seedlings), and Matlabas $\times$ RL6071/Webster $(n=601$ seedlings $)$ as well as the parents were resistant to race TTKSF. In these populations, resistance was uniformly expressed as a 1 to 2 - infection type, which was clearly different from the susceptible control (Supplementary Fig. S2).

The chromosome 2B resistance genes $\operatorname{Sr} 9 a, \operatorname{Sr} 9 b, \operatorname{Sr} 9 d$, $\operatorname{Sr} 9 e$, Sr10, Sr16, Sr19, Sr20, and $S r 23$ were ineffective to TTKSF and TTKSF+ (Table 1). Sr28 (2BL), Sr36 (2BS), Sr39 (2BS), Sr40, and $S r 47$ (2BL) were effective to both races, indicating that the

Table 2. Selected simple sequence repeat (SSR) marker profiles of lines with $\mathrm{Sr}$ genes known to occur on the chromosome $2 \mathrm{~B}$ region of interest

\begin{tabular}{|c|c|c|c|c|c|c|c|c|c|c|c|c|}
\hline Line & $S r$ gene & $\begin{array}{l}\text { Chrom. } \\
\text { location }\end{array}$ & Source & GWM148 & BARC230 & WMC592 & GWM319 & BARC167 & BARC160 & WMC441 & $\begin{array}{l}\text { IWA543- } \\
\text { HRM }^{\mathrm{a}, \mathrm{b}}\end{array}$ & GWM47 \\
\hline Line $37-07$ & Susc. control & - & $\mathrm{UFS}^{\mathrm{c}}$ sel $6 \mathrm{~A}$ & 166 & 198 & 272 & 172 & 248 & 105 & 166 & $\mathrm{~L}$ & $160^{\mathrm{d}}$ \\
\hline Matlabas e & $?$ & $2 \mathrm{BL}$ & AK $2010^{\mathrm{f}}$ & 143 & 201 & 278 & 174 & 267 & 116 & 176 & M & 183 \\
\hline $\begin{array}{l}\text { Vernstein } \\
\text { PI } 442914\end{array}$ & $9 e$ & $2 \mathrm{BL}$ & $\begin{array}{l}\text { Seventh } \\
\text { ISRTN\#11 }\end{array}$ & 162 & 200 & 270 & 174 & 257 & 110 & 158 & $\mathrm{~L}$ & - \\
\hline LCSrWst-2Wst & Wst-2 & $?$ & UFS II-80 & 145 & 175 & 270 & 174 & 260 & 110 & 162 & $\mathrm{~L}$ & 189 \\
\hline Thatcher & $\begin{array}{c}5,9 g, 12,16 \\
\quad \& A P R^{\mathrm{h}}\end{array}$ & $\begin{array}{l}9 \mathrm{~g}, 16 \& \\
\text { APR on } \\
2 \mathrm{BL}\end{array}$ & $\begin{array}{l}\text { Seventh } \\
\text { ISRTN\#83 }\end{array}$ & 164 & 209 & 276 & 172 & 236 & 105 & 160 & $\mathrm{~L}$ & null \\
\hline $\begin{array}{l}\text { Webster } \\
\text { CM661 }\end{array}$ & $9 h$ & $2 \mathrm{BL}$ & $\begin{array}{l}\text { CRC } \\
\text { Winnipegi }\end{array}$ & 143 & 175 & 270 & 174 & 260 & 110 & 162 & $\mathrm{~L}$ & 189 \\
\hline $\begin{array}{l}\text { RL6071/ } \\
\text { Webster F3 }\end{array}$ & $9 h$ & $2 \mathrm{BL}$ & $\begin{array}{l}\text { CRC } \\
\text { Winnipeg }\end{array}$ & 164 & 207 & 272 & 174 & 257 & 110 & 162 & $\mathrm{~L}$ & 189 \\
\hline RL6071 & Susc. control & - & $\begin{array}{l}\text { CRC } \\
\text { Winnipeg }\end{array}$ & 154 & 201 & 272 & 174 & 257 & 110 & 174 & M & null \\
\hline Gabo56 & $9 h$ & $2 \mathrm{BL}$ & $\begin{array}{l}\text { CRC } \\
\text { Winnipeg }\end{array}$ & 166 & 198 & 272 & 172 & 248 & 105 & 158 & $\mathrm{~L}$ & null \\
\hline PI 626573-2 & $W L R$ & $2 \mathrm{BL}$ & NDSU $^{\mathrm{j}}$ & 143 & 201 & 270 & 174 & 267 & 116 & 153 & M & 187 \\
\hline Cltr- $4311-1^{\mathrm{k}}$ & $9 h$ & $2 \mathrm{BL}$ & $\begin{array}{l}\text { USDA }^{1} \\
\text { Aberdeen }\end{array}$ & 143 & 201 & 270 & 174 & 267 & 119 & 182 & $\mathrm{~L}$ & 177 \\
\hline PI $178188-1^{\mathrm{m}}$ & $9 h$ & $2 \mathrm{BL}$ & $\begin{array}{l}\text { USDA } \\
\text { Aberdeen }\end{array}$ & 143 & 201 & 270 & 172 & 250 & 110 & 148 & $\mathrm{~L}$ & null \\
\hline PI $623118-1^{\mathrm{m}}$ & $9 h$ & $2 \mathrm{BL}$ & $\begin{array}{l}\text { USDA } \\
\text { Aberdeen }\end{array}$ & 143 & 201 & 270 & 174 & 260,267 & 110,119 & 174,181 & $\mathrm{~L}$ & 181 \\
\hline PI $623582-1^{\mathrm{m}}$ & $9 h$ & $2 \mathrm{BL}$ & $\begin{array}{l}\text { USDA } \\
\text { Aberdeen }\end{array}$ & 143 & 201 & 270 & 174 & 267 & 119 & 182 & $\mathrm{~L}$ & 179 \\
\hline PI $623785-1^{\mathrm{m}}$ & $9 h$ & $2 \mathrm{BL}$ & $\begin{array}{l}\text { USDA } \\
\text { Aberdeen }\end{array}$ & 143 & 201 & 270 & 172 & 250 & 110 & 148 & $\mathrm{~L}$ & null \\
\hline PI $625315-1^{\mathrm{m}}$ & $9 h+$ & $2 \mathrm{BL}$ & $\begin{array}{l}\text { USDA } \\
\text { Aberdeen }\end{array}$ & 139 & 201 & 278 & 174 & 263 & 116 & 178 & $\mathrm{~L}$ & 179 \\
\hline PI $625348-1^{\mathrm{m}}$ & $9 h+$ & $2 \mathrm{BL}$ & $\begin{array}{l}\text { USDA } \\
\text { Aberdeen }\end{array}$ & 143 & 201 & 270 & 174 & 267 & 119 & 181 & $\mathrm{~L}$ & 181 \\
\hline PI $626255-1^{\mathrm{m}}$ & $9 h$ & $2 \mathrm{BL}$ & $\begin{array}{l}\text { USDA } \\
\text { Aberdeen }\end{array}$ & 143 & 199 & 279 & 174 & 244 & 110 & 155 & $\mathrm{D}^{\mathrm{n}}$ & 175,183 \\
\hline PI $626409-1^{\mathrm{m}}$ & $9 h+$ & $2 \mathrm{BL}$ & $\begin{array}{l}\text { USDA } \\
\text { Aberdeen }\end{array}$ & 143 & 201 & 276 & 174 & 267 & 116 & 176 & $\mathrm{~L}$ & 183 \\
\hline PI $626491-1^{\mathrm{m}}$ & $9 h$ & $2 \mathrm{BL}$ & $\begin{array}{l}\text { USDA } \\
\text { Aberdeen }\end{array}$ & 156 & 199 & 273 & 174 & 267 & 116 & 176 & $\mathrm{~L}$ & 189 \\
\hline $\begin{array}{l}\text { a Marker with } \\
\text { b qPCR marke } \\
\text { c University o } \\
\text { d The third loc } \\
\text { e The Matlaba } \\
\text { f The AK2010 } \\
\text { g International } \\
\text { h Adult plant } \\
\text { i Cereal Rese } \\
\text { j North Dakot } \\
\text { k According to } \\
\text { l United State } \\
\text { m According to } \\
\text { n Different all }\end{array}$ & $\begin{array}{l}\text { the highest sig } \\
\mathrm{r} \text { results cluste } \\
\text { the Free Stat } \\
\text { us of the mult } \\
\text { s alleles are in } \\
\text { seed source r } \\
\text { Stem Rust Tr } \\
\text { esistance. } \\
\text { arch Centre W } \\
\text { a State Univer } \\
\text { Babiker et al } \\
\text { Department } \\
\text { Babiker et al } \\
\text { le to those in }\end{array}$ & $\begin{array}{l}\text { nificant L } \\
\mathrm{r} \text { as "M" ( } \\
\text { locus mar } \\
\text { bold. } \\
\text { fers to th } \\
\text { p Nursery } \\
\text { nnipeg. } \\
\text { ity. } \\
\text { (2016b). } \\
\text { f Agricult } \\
\text { (2016a). } \\
\text { Matlabas a }\end{array}$ & $\begin{array}{l}\text { DD score. } \\
\text { Matlabas allele } \\
\text { per GWM47 m } \\
\text { particular Ma }\end{array}$ & $\begin{array}{l}\text { or "L" (Li } \\
\text { apped to the } \\
\text { labas plant }\end{array}$ & $\begin{array}{l}\text { ne } 37-07 \text { al } \\
\text { from which }\end{array}$ & $\begin{array}{l}\text { le). } \\
\text { ne locatio } \\
\text { TKSF+ v }\end{array}$ & s isolated & 2010. & & & & \\
\hline
\end{tabular}


defeated Matlabas gene is different (Table 1). Similar to 'Matlabas', Line LCSrWst-2Wst with SrWst-2 produced a low infection type to TTKSF, but a high infection type to TTKSF+. 'Webster', PI 6265732, and an RL6071/Webster $\mathrm{F}_{3}$ line fixed for $\mathrm{Sr} 9 \mathrm{~h}$, but lacking $\mathrm{Sr} 30$, showed comparable low and high infection types to races TTKSF and TTKSF+, respectively (Table 1).

Molecular analysis, linkage mapping, and QTL analysis. A total of $68 \%$ of the 104 LRGS markers used to screen the Matlabas $\times$ Line 37-07 gDNA bulks and parents were polymorphic and represented all 21 chromosomes. This served as a sound basis to identify chromosomes that may be associated with the single gene trait under investigation. Three polymorphic chromosome 2B markers (GWM148, WMC35, and BARC160) and one multilocus (2B, 5B) marker (WMC27) amplified alleles that were present in the R-bulks and 'Matlabas', but were absent in the S-bulk and susceptible parent (Supplementary Fig. S3). This result indicated that the markers were associated with the resistance gene. All other markers amplified both the parental alleles in the R- as well as the S-bulks and were thus not associated with the resistance gene. A subset of 186 Matlabas $\times$ Line $37-07 \mathrm{~F}_{2}$ individuals was screened with the three single locus 2B markers. Kruskal-Wallis single marker regression analysis indicated significant associations between the trait and chromosome $2 \mathrm{~B}$ markers $(P<0.05)$. The parental lines were screened with an additional 74 chromosome 2B-specific SSR and HRM markers of which $32 \%$ were polymorphic. The Matlabas $\times$ Line $37-07 \mathrm{~F}_{2}$ individuals were subsequently screened with these markers, bringing the total number of polymorphic $2 \mathrm{~B}$ markers to 27 .

Seven markers remained unlinked, of which three, WMC175, CFA2043 and GWM382, were multiloci markers, while 20 markers were assigned to a 77.5 centimorgan (cM) linkage group partially covering the short arm, centromeric region, and long arm of chromosome 2B (Fig. 1).

The order of markers between the chromosome 2B linkage group from the present study and the 2B consensus maps of Appels (2003) and Somers et al. (2004) was similar with minor rearrangements between the three maps (Fig. 2). All markers where minor rearrangements

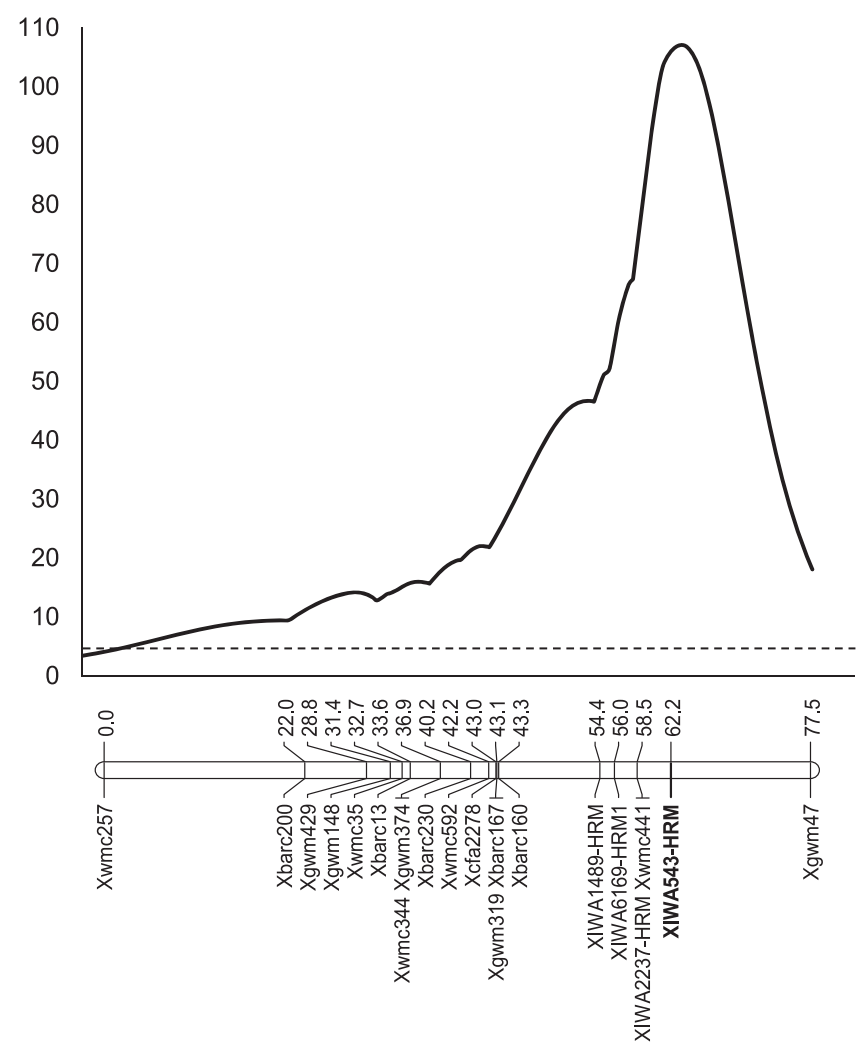

Fig. 1. LOD profile obtained with interval mapping in MapQTL V6 of the stem rust resistance gene located on chromosome arm 2BL in 'Matlabas'. The marker most significantly associated with the gene is indicated in bold. The significance level shown was determined at LOD 4.8 with 10,000 permutations. were observed occurred within a $6.4 \mathrm{cM}$ interval (Xwmc344 to Xbarc160) on the Matlabas-derived 2B map and span the region surrounding the centromere (Appels 2003; Somers et al. 2004), which was located approximately $19 \mathrm{cM}$ from the region of interest in Matlabas (Fig. 2). Additionally, the order of the two markers on the distal end of 2BS was inverted between the Somers et al. (2004) and Matlabas-derived maps. One locus mapped here (Xbarc230) was not included on either of the consensus maps, but was placed on the short arm distal to Xcfa2278 and Xgwm47 by Sourdille et al. (2004). The decision to utilize only codominant markers resulted in a 2B map comparable with other reliable maps.

All chromosome 2B markers indicated a significant association $(P<$ $0.05)$ with the trait using Kruskal-Wallis single marker regression analysis. Interval mapping performed with MapQTL V6 in the Matlabas $\times$ Line $37-07 \mathrm{~F}_{2}$ population indicated that the gene was located between XIWA543-HRM and Xgwm47 on chromosome arm 2BL (Fig. 1) with IWA543-HRM being the marker closest to the gene of interest explaining $92.6 \%$ of the phenotypic variance observed. The gene was thus defined to a region spanning $15.3 \mathrm{cM}$. For multiloci marker GWM47, both parental lines (Matlabas and Line 37-07) amplified a 126-bp product for the first locus (thus nonpolymorphic) and a dominant profile for the second (null/145 bp). Therefore, only the codominant alleles identified for the third locus of $\mathrm{Xgwm} 47$ $\left(183 \mathrm{bp} / 160 \mathrm{bp}\right.$ ) were mapped in the $\mathrm{F}_{2}$ population and scored in 20 Matlabas $\times$ Line $37-07 \mathrm{~F}_{3}$ families represented by a single $\mathrm{F}_{3}$ plant each.

Analysis of individual resistant and susceptible Matlabas $\times$ Line 37-07 $\mathrm{F}_{3}$ plants representing 20 different $\mathrm{F}_{3}$ families with markers spanning the gene region (GWM148, BARC230, WMC592, GWM319, BARC167, BARC160, WMC441, IWA543-HRM, and GWM47) validated the marker-trait associations identified in the $\mathrm{F}_{2}$ population (Table 3). The 10 resistant Matlabas $\times$ Line $37-07 \mathrm{~F}_{3}$ plants, representing families homozygous for resistance to TTKSF, amplified the same allele as in 'Matlabas' with all markers except for GWM148, which was the marker most distant $(30.8 \mathrm{cM})$ to the resistance gene. Of the 10 susceptible Matlabas $\times$ Line $37-07 F_{3}$ plants, eight amplified only the susceptible allele for GWM148.

The marker which was most significantly linked to the Matlabas $\mathrm{Sr}$ gene (IWA543-HRM) amplified the Matlabas allele in the susceptible control line that lacks $S r 9 h$ (RL6071) and in PI 626573-2 $(S r W L R)$, but not in any of the $S r 9 h$ carrying control lines including RL6071/Webster and 'Webster', all of which produced the Line 3707 allele (Table 2). IWA543-HRM detected a different allele to either 'Matlabas' or Line 37-07 in the Sr9h control line PI 626255-1. GWM47 is a multilocus marker and appeared to produce two amplicons for the third locus (175 bp and the Matlabas allele of $183 \mathrm{bp}$ ) in PI 626255-1. The two flanking SSR Matlabas alleles of Xwmc441 (176 bp) and Xgwm47 (183 bp) were not detected in either PI 626573-2 ( $S r W L R$ control) or in any of the $S r 9 h$-postulated lines except for PI 626409-1 (Sr9h+). In addition, the Xwmc441-176 bp Matlabas allele was detected in PI 626491-1 ( $\mathrm{Sr} 9 \mathrm{~h})$, but with the Matlabas alleles for IWA543-HRM and GWM47 being absent.

\section{Discussion}

The segregation ratio of the phenotypic scores on the Matlabas $x$ Line 37-07 $\mathrm{F}_{2}$ seedlings indicated that a dominant, single gene was responsible for the resistance in 'Matlabas'. The deviation from the 1:2:1 single gene segregation in the Matlabas $\times$ Line $37-07 \mathrm{~F}_{3}$ families is most likely the result of outcrossing between families in the field where they were produced without covering the spikes during anthesis. Traditionally, the chromosomal position of a major gene can be determined using qualitative trait mapping where the phenotypic trait is imported as a dominant molecular marker into the mapping software. However, using dominant markers for genetic mapping in an $\mathrm{F}_{2}$ population decreases the accuracy of a genetic map (Semagn et al. 2006). Since homozygous and heterozygous gene carriers could not be discriminated phenotypically, a QTL approach was used.

To accelerate and reduce the cost of the identification of the chromosome position of the unknown gene, a previously developed LRGS consisting of 104 SSRs located over a large genetic interval 
covering all 21 chromosomes was utilized in the present study. Although standard bulking approaches (Michelmore et al. 1991) to identify the chromosome locations of single major and partially dominant resistance genes have been used with varied success (Ghazvini et al. 2013), it was considered worthwhile to use the LRGS combined with a bulking approach as a first step to target the major $\mathrm{Sr}$ gene in 'Matlabas'. Despite the limitation of possibly working with heterozygous resistant bulks, the bulking strategy proved effective for the detection of the gene. The intermarker distances between XIWA543-HRM, closest to the gene of interest, and the three SSR marker loci initially associated with the trait in the bulks were 30.8
cM (Xgwm148), $29.5 \mathrm{cM}$ (Xwmc35), and $18.9 \mathrm{cM}$ (Xbarc160), respectively. Ghazvini et al. (2013) advocated the use of a multiple BSA, which they used effectively to locate $\mathrm{Sr} 54$, a major effect gene that was located on a large linkage block on chromosome 2D. The success of the standard BSA approach used in the present study can probably be attributed to the major resistance response of the single Matlabas $\mathrm{Sr}$ gene segregating in the population.

The region identified on chromosome arm 2BL has previously been shown to be rich in stem rust resistance, including $\mathrm{Sr} 28$ (Rouse et al. 2012), Sr47 (Klindworth et al. 2012), Sr9h (formerly SrWeb; Hiebert et al. 2010; Rouse et al. 2014), and SrWLR (Zurn et al.

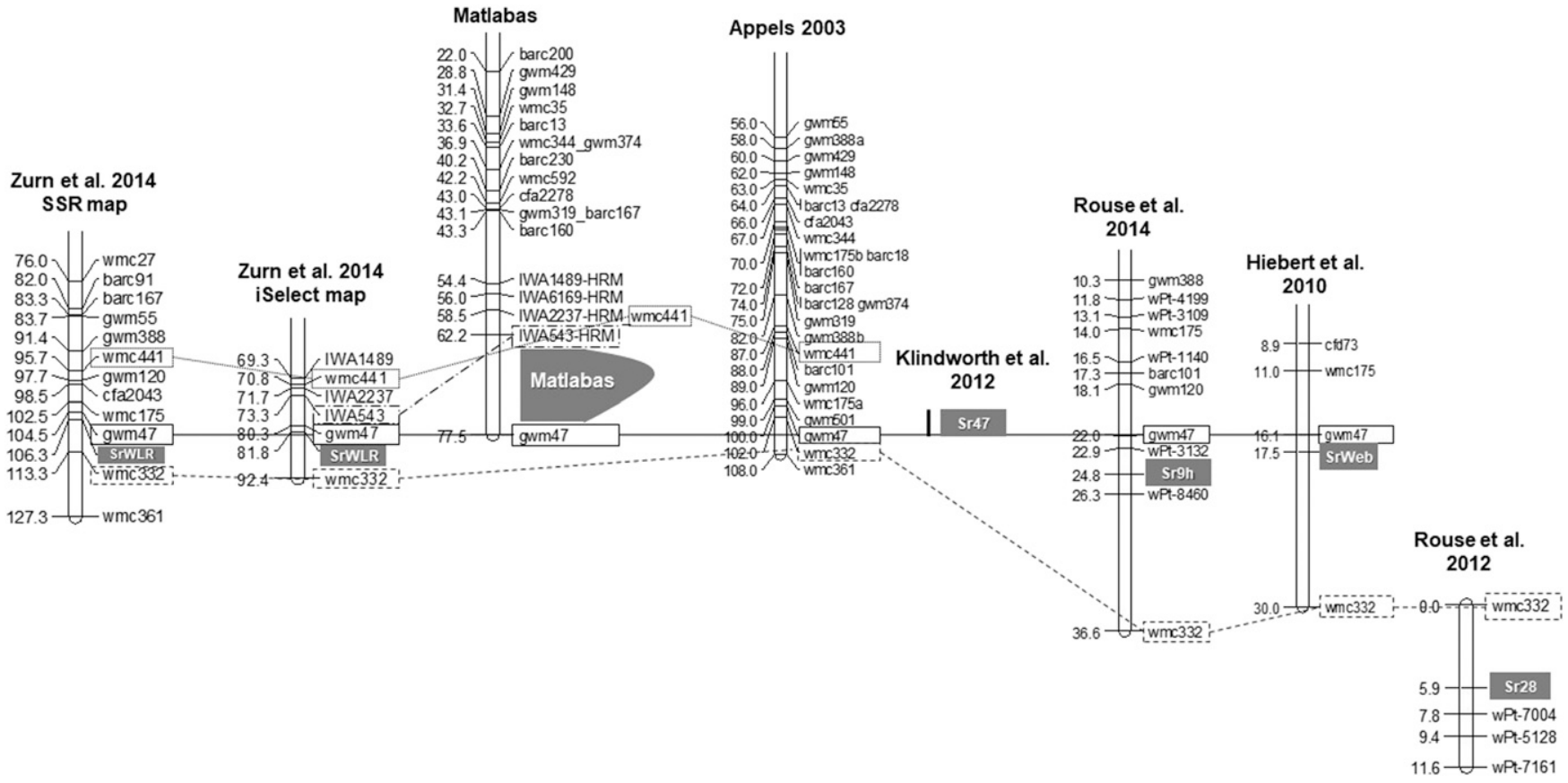

Fig. 2. Comparison of published genetic maps pertaining to the chromosome region of interest in 'Matlabas'. Other stem rust resistance genes previously mapped in the area are indicated in gray.

Table 3. Genotypes of individual $\mathrm{F}_{3}$ plants representing different $\mathrm{F}_{3}$ families screened with simple sequence repeat (SSR) markers spanning the Matlabas $\mathrm{Sr}$ gene region

\begin{tabular}{|c|c|c|c|c|c|c|c|c|c|c|c|c|c|c|c|c|c|}
\hline \multirow{2}{*}{$\frac{\text { Line }}{\text { Matlabas }^{\mathrm{c}}}$} & \multicolumn{2}{|c|}{ GWM148 } & \multicolumn{2}{|c|}{ BARC230 } & \multicolumn{2}{|c|}{ WMC592 } & \multicolumn{2}{|c|}{ GWM319 } & \multicolumn{2}{|c|}{ BARC167 } & \multicolumn{2}{|c|}{ BARC160 } & \multicolumn{2}{|c|}{ WMC441 } & \multirow{2}{*}{$\frac{\text { IWA543-HRM }^{\mathrm{a}, \mathrm{b}}}{M}$} & \multicolumn{2}{|c|}{ GWM47 } \\
\hline & 143 & & & 201 & & 278 & & 174 & & 267 & & 116 & & 176 & & & $\overline{183}$ \\
\hline Line $37-07$ & & 166 & 198 & & 272 & & 172 & & 248 & & 105 & & 166 & & $\mathrm{~L}$ & 160 & \\
\hline KW203_R ${ }^{d}$ & & 166 & & 201 & & 278 & & 174 & & 267 & & 116 & & 176 & $\mathbf{M}$ & & 183 \\
\hline KW215_R & 143 & & & 201 & & 278 & & 174 & & 267 & & 116 & & 176 & $\mathbf{M}$ & & 183 \\
\hline KW216_R & & 166 & & 201 & & 278 & & 174 & & 267 & & 116 & & 176 & M & & 183 \\
\hline KW231_R & 143 & & & 201 & & 278 & & 174 & & 267 & & 116 & & 176 & M & & 183 \\
\hline KW233_R & 143 & & & 201 & & 278 & & 174 & & 267 & & 116 & & 176 & $\mathbf{M}$ & & 183 \\
\hline KW245_R & 143 & & & 201 & & 278 & & 174 & & 267 & & 116 & & 176 & $\mathbf{M}$ & & 183 \\
\hline KW256_R & 143 & & & 201 & & 278 & & 174 & & 267 & & 116 & & 176 & $\mathbf{M}$ & & 183 \\
\hline KW259_R & 143 & 166 & 198 & 201 & 272 & 278 & 172 & 174 & 248 & 267 & 105 & 116 & & 176 & M & & 183 \\
\hline KW261_R & 143 & 166 & 198 & 201 & 272 & 278 & 172 & 174 & 248 & 267 & 105 & 116 & 166 & 176 & M & & 183 \\
\hline KW262_R & 143 & & & 201 & & 278 & & 174 & & 267 & & 116 & & 176 & M & & 183 \\
\hline KW200_S & & 166 & 198 & & 272 & & 172 & & 248 & & 105 & & 166 & & $\mathrm{~L}$ & 160 & \\
\hline KW212_S & & 166 & 198 & & 272 & & 172 & & 248 & & 105 & & 166 & & $\mathrm{~L}$ & 160 & \\
\hline KW214_S & & 166 & 198 & & 272 & & 172 & & 248 & & 105 & & 166 & & $\mathrm{~L}$ & 160 & \\
\hline KW232_S & & 166 & 198 & & 272 & & 172 & & 248 & & 105 & & 166 & & $\mathrm{~L}$ & 160 & \\
\hline KW241_S & & 166 & 198 & 201 & 272 & 278 & 172 & 174 & 248 & 267 & 105 & 116 & 166 & & $\mathrm{~L}$ & 160 & \\
\hline KW247_S & & 166 & 198 & & 272 & & 172 & & 248 & & 105 & & 166 & & $\mathrm{~L}$ & 160 & \\
\hline KW249_S & & 166 & 198 & & 272 & & 172 & & 248 & & 105 & & 166 & & $\mathrm{~L}$ & 160 & \\
\hline KW252_S & & 166 & 198 & & 272 & & 172 & & 248 & & 105 & & 166 & & $\mathrm{~L}$ & 160 & \\
\hline KW258_S & 143 & 166 & 198 & & 272 & & 172 & & 248 & & 105 & & 166 & & $\mathrm{~L}$ & 160 & \\
\hline KW260_S & 143 & 166 & & 201 & & 278 & & 174 & & 267 & & 116 & 166 & & $\mathrm{~L}$ & 160 & \\
\hline
\end{tabular}

${ }^{a}$ Marker with the highest significant LOD score.

${ }^{\mathrm{b}}$ qPCR marker results cluster as "M" (Matlabas allele) or "L" (Line 37-07 allele).

c The Matlabas alleles are in bold.

${ }^{\mathrm{d}} \mathrm{R}=$ resistant and $\mathrm{S}=$ susceptible to Puccinia graminis $\mathrm{f}$. $\mathrm{sp}$. tritici race TTKSF. 
2014). Rouse et al. (2012) mapped $S r 285.9 \mathrm{cM}$ distal to Xwmc332, which, according to the consensus map of Appels (2003), is located 2 cM distal to $X g w m 47$. Since $X g w m 47$ is located $15.3 \mathrm{cM}$ distal from the Matlabas $\mathrm{Sr}$ gene, it implies an even further map distance of 23.2 cM between $\mathrm{Sr} 28$ and the gene of interest (Fig. 2). Evidence that $\mathrm{Sr} 28$ is effective against TTKSF+ and other members of the Ug99 race group (Singh et al. 2015) supports the results of the genetic map comparisons that the $\mathrm{Sr}$ gene in 'Matlabas' is not $\mathrm{Sr} 28$.

Sr47 derived from Aegilops speltoides has previously been mapped close to Xgwm501 and Xgwm47 in durum wheat, placing it in the region of the Matlabas $S r$ gene (Klindworth et al. 2012; Fig. 2). $S r 47$ is derived from a wild relative of wheat not in the pedigree of 'Matlabas'. Also, line DAS15, which has Sr47, showed low infection types to both TTKSF and TTKSF+ (Table 1). These results support the hypothesis that the stem rust resistance in 'Matlabas' is not due to $\mathrm{Sr} 47$.

Other Ug99 effective genes on 2BL (i.e., $S r 9 h, S r W L R$, and the $S r$ gene in 'Matlabas') were susceptible to TTKSF+ (Table 1; Babiker et al. 2016a; Rouse et al. 2012; Zurn et al. 2014) and mapped to the same 2BL region (Yu et al. 2014; Fig. 2). The 1 to 2 low infection type of 'Webster' (Sr9h/SrWeb) and PI 626573 (SrWLR) to TTKSK (Hiebert et al. 2010; Zurn et al. 2014) closely resembles the Matlabas TTKSF phenotype (TTKSF is similar to TTKSK except for avirulence to $S r 31$ ). Based on infection type data the gene in 'Webster', LCSrWst-2Wst, and the line RL6071/Webster (Table 1), appears to be the same resistance gene $(\mathrm{Sr} 9 \mathrm{~h} / \mathrm{SrWeb})$ which broke down in 'Matlabas'. The specificity of SrWst-2 toward TTKSF and TTKSF+, together with the fact that this gene was also transferred from 'Webster' (Roelfs et al. 1992), indicate it may be $S r 9 h$. Infection type data with TTKSF and TTKSF+ from Rouse et al. (2014) and Babiker et al. (2016a) correspond to this postulation. Results from the allelism tests performed by test crossing 'Matlabas' with 'Webster', CItr 4311 and line RL6071/Webster previously confirmed to carry Sr9h (Babiker et al. 2016b; Hiebert et al. 2010; Rouse et al. 2014) further supported the hypothesis based on infection types that the gene in 'Matlabas' is $\mathrm{Sr} 9 \mathrm{~h}$. All progeny from the three crosses were resistant to race TTKSF, indicating the presence of the same dominant resistance gene in the respective parental lines.

Rouse et al. (2014) mapped $\mathrm{Sr} 9 \mathrm{~h} 2.8 \mathrm{cM}$ distal to $\mathrm{Xgwm} 47 \mathrm{using}$ a Gabo56 $\times$ Chinese Spring $\mathrm{F}_{2}$ population ( 80 individuals for genotyping). They used seven SSRs and the stem rust resistance as a bridge to incorporate dominant markers in a combined map consisting of both dominant and codominant marker types. Hiebert et al. (2010) used a larger $\mathrm{F}_{2}$ population (174) and placed $\mathrm{SrWeb}$ (Sr9h) $1.4 \mathrm{cM}$ distal to Xgwm47 using six SSRs, of which two (WMC175, GWM47) were inherited in a dominant fashion. Most of the markers on the 2BL Matlabas-derived map (Fig. 2) are in common with the various studies on genes in these regions except for the multiallelic markers (WMC175, CFA2043, and GWM382) of which the polymorphic allele remained unlinked, indicating a different chromosome position. Given the $15.3 \mathrm{cM}$ interval between XIWA543-HRM and Xgwm47 and the previously mapped distances of $1.4 \mathrm{cM}(\mathrm{SrWeb})$ and $2.8 \mathrm{cM}(\mathrm{Sr} 9 \mathrm{~h})$ distal from Xgwm47, distances of $16.7 \mathrm{cM}$ and $18.1 \mathrm{cM}$, respectively, are implied between XIWA543-HRM and $\mathrm{SrWeb/Sr} 9 \mathrm{~h}$ (Fig. 2). However, HRM marker IWA543-HRM was derived from the SNP marker IWA543 on the 9K Illumina Infinium iSelect wheat assay, which is located on the long arm of chromosome 2B at $109.53 \mathrm{cM}$ (Wang et al. 2014). This is the exact location of a gene hypothesized to be $\operatorname{Sr} 9 \mathrm{~h}$ (Babiker et al. 2016b), and overlaps with the map position of the gene in 'Matlabas'.

Zurn et al. (2014) mapped $\operatorname{Sr} W L R$ in the same region as $\operatorname{Sr} 9 h, 1.5$ cM distal to Xgwm47, in Iranian landrace accession PI 626573 (Fig. 2) using a large set of SSR and SNP markers. Marker analysis with 12 SNP markers flanking SrWLR revealed that PI 626573 and the cultivar 'Webster' ( $\mathrm{Sr} 9 \mathrm{~h} / \mathrm{SrWeb})$ amplified different alleles, indicating that $S r W L R$ and $S r 9 h$ may not be the same (Zurn et al. 2014). SrWLR provides resistance to North American race RKQQC, whereas it is unknown whether $S r 9 h$ in 'Webster' provides resistance to race RKQQC due the presence of Sr30 (Zurn et al. 2014). However,
Cltr-4311-1 showed resistance to race RKQQC and likely carries Sr9h (Babiker et al. 2016b).

Marker analysis of the gene region of lines known to carry some of the known $\mathrm{Sr}$ genes on chromosome arm 2BL did not provide clear confirmation of the identity of the Matlabas gene (Table 2). The amplicon for the marker most significantly linked to the gene (IWAS543-HRM) in 'Matlabas' was only in agreement with the SrWLR control (Iranian landrace PI 626573-2), while the two flanking loci (Xwmc441 and Xgwm47) differed for this line. Furthermore, IWA543-HRM amplified the Matlabas allele in the line not carrying Sr9h (RL6071, pedigree Prelude/8*Marquis*2/3/Prelude//Prelude/8*Marquis). Neither IWA543-HRM, nor the flanking SSR markers WMC441 and GWM47, amplified the same alleles in 'Matlabas' as in the $13 \mathrm{Sr} 9 \mathrm{~h}$ control lines. Among the haplotypes of these control lines, none was associated with $\mathrm{Sr} 9 \mathrm{~h}$ across all of the lines, even though most of these accessions are landraces from the same country of origin (Babiker et al. 2016b). A possible explanation is the distal map location of the gene where crossovers are more likely to occur.

The identity and relationships of the genes in this region of the long arm of chromosome $2 \mathrm{~B}$ need further clarification. One of the main issues is the discrepancies in map positions reported for these genes. The area in which these genes are located remains contested in terms of marker order, which could be the result of different marker types and population types and sizes used by the various groups investigating these genes (Hiebert et al. 2010). The use of dominant markers such as GWM47, the marker linked to $\mathrm{Sr} 9 \mathrm{~h}$ (Babiker et al. 2016b; Hiebert et al. 2010; Rouse et al. 2014), decreases the accuracy of the genetic map, specifically in $\mathrm{F}_{2}$ populations, in terms of marker order as $50 \%$ of the individuals are heterozygous and cannot be discriminated from the homozygous individuals (Semagn et al. 2006; Xu 2010).

Using competitive allele-specific PCR (KASP) assays, Babiker et al. (2016b) identified markers closely linked to a gene suspected to be $\mathrm{Sr} 9 \mathrm{~h}$. However, Zurn et al. (2014) was not able to identify SNPs that could discriminate between and serve as diagnostic markers for either $\operatorname{Sr} W L R, S r 9 h$, or any of the $\operatorname{Sr} 9$ alleles despite mapping 2,846 polymorphic SNP markers (9K Illumina Infinium iSelect). Thus, diagnostic markers are needed for the stem rust resistance genes in this region of chromosome $2 \mathrm{BL}$, which will most likely be achieved through cloning of the genes in this region (Zurn et al. 2014). With the availability of the annotated wheat genome (IWGSC 2018), this objective has become more feasible. Nonetheless, similar to Rouse et al. (2014), the allelism tests in the present study support the hypothesis that the Matlabas resistance gene is $\mathrm{Sr} 9 \mathrm{~h}$.

Before the discovery of TTKSF+ and based on available data, 'Matlabas' was resistant to stem rust. However, more recent work with TTKSF isolates in the rust culture collection at University of the Free State determined that a 2003 isolate of $P$. graminis $\mathrm{f}$. sp. tritici was mixed for avirulence and virulence on line LCSrWst-2Wst (Singh et al. 2015). A purified subculture confirmed virulence for 'Matlabas' and thus provided evidence that race TTKSF+ was present in South Africa before its collection in 2010. Since lines vulnerable to this race (such as $\mathrm{Sr} 9 \mathrm{~h}$ ) were not part of the differential sets before 2010, the occurrence of TTKSF+ went unnoticed. Furthermore, TTKSF+ was also observed in a stem rust sample collected at Birchenough, Zimbabwe in September 2010 (Pretorius et al. 2012). Without additional testing of historic isolates, it is not possible to determine whether TTKSF+ survived in South Africa at low frequencies or whether it was reintroduced from Zimbabwe in 2010. From survey data, Terefe et al. (2016) reported that TTKSF+ was infrequently detected in South Africa. The race occurred in the Free State in 2010, whereas three $P$. graminis f. sp. tritici collections from the Western Cape were identified as TTKSF+ in 2013, the latter of which was unexpected since only spring types are grown in the Western Cape and none of the commercial spring wheats is known to carry Sr9h or SrWLR.

Considering published pedigree information on released South African wheat cultivars, 'Matlabas' is the only cultivar with Saulesku28 in its pedigree (Smit et al. 2010). Since Tugela-DN is susceptible 
to all members of the $\mathrm{Ug} 99$ race group, the Matlabas gene was likely transferred from Saulesku-28. Unfortunately, seed of Saulesku-28 could not be procured for stem rust screening in the present study, and the pedigree history of this line is not retrievable (N. Saulescu, personal communication). Annual seedling infection type data (not presented) for South African cultivars and advanced breeding lines showed that 'Matlabas' is the only commercial cultivar resistant to the original TTKSF isolate (accession no. 2013) collected in 2000 (Boshoff et al. 2002) and susceptible to isolate UVPgt61/1 of race TTKSF+ sampled from Matlabas plants. Based on phenotypic data less than $5 \%$ of breeding lines carry the Matlabas gene. It is thus unlikely that race TTKSF+ will threaten wheat production in South Africa at the present time. The downfall of the resistance in 'Matlabas' follows a similar pattern as $\mathrm{Sr} 24, \mathrm{Sr} 31, \mathrm{Sr} 36$, and $\mathrm{SrTmp}$, confirming the nondurability of major-gene resistance to the Ug99 African race group. This unfortunate trend further exemplifies the need for continuous pathogen monitoring and importance of resistance gene stewardship.

\section{Acknowledgments}

Dr. Colin Hiebert and Dr. Mike Bonman are thanked for providing seed of lines used as $\mathrm{Sr} 9 h$ controls. Karen Wolmarans is thanked for technical assistance.

\section{Literature Cited}

Akbari, M., Wenzl, P., Caig, V., Carling, J., Xia, L., Yang, S., Uszynski, G., Mohler, V., Lehmensiek, A., Kuchel, H., Hayden, M. J., Howes, N., Sharp, P., Vaughan, P., Rathmell, B., Huttner, E., and Kilian, A. 2006. Diversity arrays technology (DArT) for high-throughput prowling of the hexaploid wheat genome. Theor. Appl. Genet. 113:1409-1420.

Anonymous. 2007. Production guidelines for the production of small grains in the summer rainfall area. Small Grain Institute, Bethlehem, South Africa.

Anonymous. 2011. South African wheat crop quality report 2010/2011 season. Southern African Grain Laboratory, Pretoria, South Africa.

Appels, R. 2003. A consensus molecular genetic map of wheat - a cooperative international effort. Pages 211-214 in: Proceedings of the tenth International Wheat Genetics Symposium, 1-6 September, Paestum, Italy, vol. 1. N. E. Pogna, M. Romanò, E. A. Pogna, and G. Galterio, eds. Istituto Sperimentale per la Cerealicoltura, Rome, Italy.

Babiker, E. M., Gordon, T. C., Bonman, J. M., Chao, S., Rouse, M. N., BrownGuedira, G., Williamson, S., and Pretorius, Z. A. 2016a. Rapid identification of resistance loci effective against Puccinia graminis f. sp. tritici race TTKSK in 33 spring wheat landraces. Plant Dis. 100:331-336.

Babiker, E. M., Gordon, T. C., Chao, S., Rouse, M. N., Wanyera, R., Newcomb, M., Brown-Guedira, G., Pretorius, Z. A., and Bonman, J. M. 2016b. Genetic mapping of resistance to the Ug99 race group of Puccinia graminis f. sp. tritici in a spring wheat landrace CItr 4311. Theor. Appl. Genet. 129: 2161-2170.

Bansal, U. K., Zwart, R., Bhavani, S., Wanyera, R., Gupta, V., and Bariana, H. S. 2012. Microsatellite mapping identifies TTKST-effective stem rust resistance gene in wheat cultivar VL404 and Janz. Mol. Breed. 30:1757-1765.

Boshoff, W. H. P., Pretorius, Z. A., Van Niekerk, B. D., and Komen, J. S. 2002. First report of virulence in Puccinia graminis f. sp. tritici to wheat stem rust resistance genes $\operatorname{Sr} 8 B$ and $\operatorname{Sr} 38$ in South Africa. Plant Dis. 86:922.

Cavanagh, C. R., Chao, S., Wang, S., Huang, B. E., Stephen, S., Kiani, S., Forrest, K., Saintenac, C., Brown-Guedira, G. L., Akhunova, A., See, D., Bai, G., Pumphrey, M., Tomar, L., Wong, D., Kong, S., Reynolds, M., Da Silva, M. L., Bockelman, H., Talbert, L., Anderson, J., Dreisigacker, S., Baenziger, S., Carter, A., Korzun, V., Morrell, P. L., Dubcovsky, J., Morell, M. K., Sorrells, M. E., Hayden, M. J., and Akhunov, E. 2013. Genome-wide comparative diversity uncovers multiple targets of selection for improvement in hexaploid wheat landrace and cultivars. Proc. Natl. Acad. Sci. 110: 8057-8062.

Doyle, J. J., and Doyle, J. 1990. A rapid total DNA preparation procedure for fresh plant tissue. Focus 12:13-15.

Ghazvini, H., Hiebert, C. W., Thomas, J. B., and Fetch, T. 2013. Development of a multiple bulked segregant analysis (MBSA) method used to locate a new stem rust resistance gene (Sr54) in the winter wheat cultivar Norin 40. Theor. Appl. Genet. 126:443-449.

Hiebert, C. W., Fetch, T. G., Jr., and Zegeye, T. 2010. Genetics and mapping of stem rust resistance to Ug99 in the wheat cultivar Webster. Theor. Appl. Genet. 121:65-69.

Hodson, D. P. 2011. Shifting boundaries: Challenges for rust monitoring. Euphytica 179:93-104

Jin, Y., Szabo, L. J., Pretorius, Z. A., Singh, R. P., Ward, R., and Fetch, T., Jr. 2008. Detection of virulence to resistance gene $\mathrm{Sr} 24$ within race TTKS of Puccinia graminis f. sp. tritici. Plant Dis. 92:923-926.

Klindworth, D. L., Niu, Z., Chao, S., Friesen, T. L., Jin, Y., Faris, J. D., Cai, X., and $\mathrm{Xu}, \mathrm{S}$. S. 2012. Introgression and characterization of a goatgrass gene for a high level of resistance to Ug99 stem rust in tetraploid wheat. G3 (Bethesda) 2: 665-673.

Koressaar, T., and Remm, M. 2007. Enhancements and modifications of primer design program Primer3. Bioinformatics 23:1289-1291.

Kosambi, D. D. 1943. The estimation of map distances from recombination values. Ann. Eugen. 12:172-175.

McIntosh, R. A., and Pretorius, Z. A. 2011. Borlaug Global Rust Initiative provides momentum for wheat rust research. Euphytica 179:1-2

Michelmore, R. W., Paran, I., and Kesseli, R. V. 1991. Identification of markers linked to disease-resistance genes by bulked segregant analysis: A rapid method to detect markers in specific genomic regions by using segregating populations. Proc. Natl. Acad. Sci. USA 88:9828-9832.

Park, R., Fetch, T., Hodson, D., Jin, Y., Nazari, K., Prashar, M., and Pretorius, Z. 2011. International surveillance of wheat rust pathogen: progress and challenges. Euphytica 179:109-117.

Patpour, M., Hovmøller, M. S., Shahin, A. A., Newcomb, M., Olivera, P., Jin, Y., Luster, D., Hodson, D., Nazari, K., and Azab, M. 2016. First report of the Ug99 race group of wheat stem rust, Puccinia graminis f. sp. tritici, in Egypt in 2014 Plant Dis. 100:863

Pretorius, Z. A., Singh, R. P., Wagoire, W. W., and Payne, T. S. 2000. Detection of virulence to wheat stem rust resistance gene $S r 31$ in Puccinia graminis f. sp. tritici in Uganda. Plant Dis. 84:203.

Pretorius, Z. A., Szabo, L. J., Boshoff, W. H. P., Herselman, L., and Visser, B. 2012. First report of a new TTKSF race of wheat stem rust (Puccinia graminis f. sp. tritici) in South Africa and Zimbabwe. Plant Dis. 96:590.

Roelfs, A. P., Singh, R. P., and Saari, E. E. 1992: Rust Diseases of Wheat: Concepts and Methods of Disease Management. CIMMYT, Mexico, D.F, Mexico. Page 18

Rouse, M. N., Nava, I. C., Chao, S., Anderson, J. A., and Jin, Y. 2012 Identification of markers linked to the race Ug99 effective stem rust resistance gene Sr28 in wheat (Triticum aestivum L.). Theor. Appl. Genet. 125:877-885

Rouse, M. N., Nirmala, J., Jin, Y., Chao, S., Fetch, T. G., Jr., Pretorius, Z. A., and Hiebert, C. W. 2014. Characterization of $S r 9 h$, a wheat stem rust resistance allele effective to Ug99. Theor. Appl. Genet. 127:1681-1688.

Semagn, K., Bjørnstad, Å., and Ndjiondjop, M. N. 2006. Principles, requirements and prospects of genetic mapping in plants. Afr. J. Biotechnol. 5:2569-2587.

Singh, R. P., Hodson, D. P., Huerta-Espino, J., Jin, Y., Bhavani, S., Njau, P., Herrera-Foessel, S., Singh, P. K., Singh, S., and Govindan, V. 2011. The emergence of Ug99 races of the stem rust fungus is a threat to world wheat production. Annu. Rev. Phytopathol. 49:465-481.

Singh, R. P., Hodson, D. P., Jin, Y., Lagudah, E. S., Ayliffe, M. A., Bhavani, S., Rouse, M. N., Pretorius, Z. A., Szabo, L. J., Huerta-Espino, J., Basnet, B. R., Lan, C., and Hovmøller, M. S. 2015. Emergence and spread of new races of wheat stem rust fungus: Continued threat to food security and prospects of genetic control. Phytopathology 105:872-884

Smit, H. A., Tolmay, V. L., Barnard, A., Jordaan, J. P., Koekemoer, F. P., Otto, W M., Pretorius, Z. A., Purchase, J. L., and Tolmay, J. P. C. 2010. An overview of the context and scope of wheat (Triticum aestivum) research in South Africa from 1983 to 2008. S. Afr. J. Plant Soil 27:81-96.

Somers, D. J., Isaac, P., and Edwards, K. 2004. A high-density microsatellite consensus map for bread wheat (Triticum aestivum L.). Theor. Appl. Genet. 109:1105-1114

Sourdille, P., Singh, S., Cadalen, T., Brown-Guedira, G. L., Gay, G., Qi, L., Gill, B. S., Dufour, P., Murigneux, A., and Bernard, M. 2004. Microsatellitebased deletion bin system for the establishment of genetic-physical map relationships in wheat (Triticum aestivum L.). Funct. Integr. Genomics 4: $12-25$.

Stakman, E. C., Stewart, D. M., and Loegering, W. Q. 1962. Identification of physiologic races of Puccinia graminis var. tritici. U.S. Dep. Agric., Agric. Res. Serv. E-617.

Terefe, T., Visser, B., and Pretorius, Z. A. 2016. Variation in Puccinia graminis $\mathrm{f}$ sp. tritici detected on wheat and triticale in South Africa from 2009 to 2013. Crop Prot. 86:9-16.

Tsilo, T. J., Jin, Y., and Anderson, J. A. 2007. Microsatellite markers linked to stem rust resistance allele $S r 9 a$ in wheat. Crop Sci. 47:2013-2020.

Untergasser, A., Cutcutache, I., Koressaar, T., Ye, J., Faircloth, B. C., Remm, M. and Rozen, S. G. 2012. Primer3 - new capabilities and interfaces. Nucleic Acids Res. 40:e115.

Van Ooijen, J. W. 2006. JoinMap 4, Software for the calculation of genetic linkage maps in experimental populations. Kyazma B.V., Wageningen, Netherlands.

Van Ooijen, J. W. 2009. MapQTL 6, Software for the mapping of quantitative trait loci in experimental populations of diploid species. Kyazma B.V., Wageningen, Netherlands.

Van Ooijen, J. W. 2011. Multipoint maximum likelihood mapping in a full-sib family of an outbreeding species. Genet. Res. Camb 93:343-349.

Visser, B., Herselman, L., and Pretorius, Z. A. 2009. Genetic comparison of Ug99 with selected South African races of Puccinia graminis f. sp. tritici. Mol. Plant Pathol. 10:213-222

Wang, S., Wong, D., Forrest, K., Allen, A., Chao, S., Huang, B. E., Maccaferri, M., Salvi, S., Milner, S. G., Cattivelli, L., Mastrangelo, A. M., Whan, A., Stephen, S., Barker, G., Wieseke, R., Plieske, J., Lillemo, M., International Wheat Genome Consortium, Mather, D., Appels, R., Dolferus, R., Brown-Guedira, 
G., Korol, A., Akhunova, A. R., Feuillet, C., Salse, J., Morgante, M., Pozniak, C., Luo, M., Dvorak, J., Morell, M., Dubcovsky, J., Ganal, M., Tuberosa, R., Lawley, C., Mikoulitch, I., Cavanagh, C., Edwards, K. J., Hayden, M., and Akhunov, E. 2014. Characterization of polyploid wheat genomic diversity using a high-density 90000 single nucleotide polymorphism array. Plant Biotechnol. J. 12:787-796.

Wessels, E., and Prins, R. 2017. Development of a low-resolution genome scan marker set for the acceleration of major gene or QTL mapping in wheat. S. Afr. J. Plant Soil 34:155-158.
$\mathrm{Xu}$, Y. 2010: Molecular Breeding Tools: Markers and Maps. Molecular Plant Breeding. CABI, Wallingford, Oxfordshire. Pages 21-43

Yu, L.-X., Barbier, H., Rouse, M. N., Singh, S., Singh, R. P., Bhavani, S., HuertaEspino, J., and Sorrells, M. E. 2014. A consensus map for Ug99 stem rust resistance loci in wheat. Theor. Appl. Genet. 127:1561-1581.

Zurn, J. D., Newcomb, M., Rouse, M. N., Jin, Y., Chao, S., Sthapit, J., See, D. R. Wanyera, R., Njau, P., Bonman, J. M., Brueggeman, R., and Acedevo, M. 2014 High-density mapping of a resistance gene to Ug99 from the Iranian landrace PI 626573. Mol. Breed. 34:871-881. 